Journal of Social Sciences (COES\&RJ-JSS)

ISSN (E): 2305-9249 ISSN (P): 2305-9494

Publisher: Centre of Excellence for Scientific \& Research Journalism, COES\&RJ LLC

Online Publication Date: $1^{\text {st }}$ July 2017

Online Issue: Volume 6, Number 3, July 2017

https://doi.org/10.25255/jss.2017.6.3.504.517

\title{
An implementation of character education for character education in elementary schools
}

Endah Sri Rahayu, Sa'dun Akbar, Murtiningsih

Study Program of Elementary School Teacher Education

Faculty of Education, Universitas Negeri Malang

Malang, East Java, Indonesia

\begin{abstract}
:
This study aims to describe the implementation, internalization, characters that appear on students, teachers and the bottlenecks and solutions in the implementation of character education in thematic learning in grade IV Public Elementary School Rampal Celaket 1 Malang. Data were collected by observation technique, interview and documentation from informant in field that is elementary school grade IV. Data analysis consists of overall data exposure, data reduction and verification. Check the validity of the findings with observational persistence techniques and method triangulation. The result of the research shows that the fourth grade teachers have to internalize character values on thematic learning through syllabism and teaching design, learning process, attitude evaluation and follow up learning. Characters that appear on students in the learning process that is religious, honest, tolerance, discipline, self, love of country, respect for achievement, curiosity, communicative, caring environment, social care, and responsibility.
\end{abstract}

\section{Keywords:}

character education, thematic learning

\section{Citation:}

Rahayu, Endah Sri; Akbar, Sa'dun; Murtiningsih (2017); An implementation of character education for character education in elementary schools; Journal of Social Sciences (COES\&RJ-JSS), Vol.6, No.3, pp:504-517; https://doi.org/10.25255/jss.2017.6.3.504.517. 


\section{Introduction}

Character education is the central theme of Indonesian education. The Indonesian government feels that building students character values not only through education in their families but also through education from kindergarden through high school. Some cases are related to the morality of student characters such as intimidation (forcing someone to do something by scaring them) among students, attacking by striking and attacking not only among our youth but also among students. Why do some students behave heartlessly or act in an unethical way? All these cases make the parents and the government concerned, so that today the government has planned and have strived in every process of learning should be inserted the character's learning so that later generations of dignitaries will be created.

According to Elias, White, \& Stepney (2014) (in Casey, Cort and Kinkopf, Timothy 2016) connecting morality with social and emotional learning. Social and emotional learning is "the ability to recognize and manage emotions, solve problems effectively, set and achieve positive goals, appreciate the perspectives of others, build and maintain positive relationships, make responsible decisions, and constructively handling interpersonal situations." Turning to a negative alternative, some teachers decide to focus on positive learning in changing their students' mindset through teaching and modeling positive behaviors rather than simply punishing students for misbehaving. Teachers handle this issue every day. They often note that students who have behavioral problems in the classroom lack empathy and sympathy for other students. Many teachers watch selfish students. Often, this causes delinquency in the classroom and forces administrators or teachers to punish this behavioral problem. This pattern has a direct impact on the level of detention, suspension, and expulsion and ultimately undermines the school culture itself.

What exactly is the difficulty in building character education in the classroom?

According to Casey, Cort and Kinkopf, Timothy (2016), first, the lack of classroom time is a major factor preventing teachers from teaching character education, while both are situations of negative cultural conditions of the home environment that diminish the positive character development of students.

According to Big Dictionary of Indonesian Language (KBBI), education is a process of changing the attitude and behavior of a person or group of people in an effort to mature human beings through the efforts of teaching and training and education. Education is a process that helps grow, grow, mature, discipline, and directly. Education also means developing the potential of a person who grows and benefits both for himself and for society.

While the term character literally comes from the Latin word "character", is the nature of the human mind that affect the whole of mind and behavior, such as character, temperament, mental traits, character, personality or character that characterizes a person. Character education is an effort that is designed and implemented systematically to help students understand the values of human behavior associated with the Almighty God, ourselves, our fellow human beings, the environment, and nationality embodied in thoughts, attitudes, feelings, words, and deeds based on norms of religion, law, etiquette, culture, and customs. 
Character education teaches ways of thinking and behaving that can support and individuals to live and work together as a family, community members, and as citizens. Character education teaches students to think brilliantly, to activate the midbrain naturally. There are four types of character education: 1) religious character education which is the absolute truth of God 2) character education based on cultural values, such as morals, Pancasila, literary appreciation, examples of leaders, etc.; 3) character education in basic environment; 4) Character education on the basis of self-potential that can be used to improve education Khan (2010: 1-2) in Nugrahaeni (2015).

According to the Ministry of National Education (in Wibowo, 2013: 13) states that character education is "education to instill and develop the characters sublime to the students, so that they have the character noble, implement and practice in life, whether in the family, as a member of society and citizens ". To that end, character education can be implemented since the students were in elementary school in order to have a high understanding and awareness to apply the virtues in everyday life day. There 18 values in the educational development of culture and national character created by the Ministry of National Education. Beginning in the 2011 academic year, all levels of education in Indonesia must include such character education in their educational process: (1) Religious, is obedience and supremacy in understanding and implementing religious teachings (beliefs) are adhered to, including in this case is a tolerant attitude to the implementation of religious worship (beliefs) other, and live harmoniously and side by side. (2) Honestly, those attitudes and behaviors that reflect the unity of knowledge, words, and deeds (knowing what is right, telling the truth, and doing the right thing) to make the person as a trustworthy person. (3) Tolerance, is attitudes and behaviors that reflect respect for different religions, beliefs, ethnicities, customs, languages, races, ethnicities, opinions, and other things that are different from itself consciously and openly and can live in peace amid such differences. (4) Discipline, consistent habits, and actions against any form of regulation or rules of conduct. (5) Hard work, a behavior that shows a serious effort (struggling to the death) in completing various tasks, problems, work, and others with the best. (6) Creativity, the attitudes, and behaviors that reflect innovation in many ways to solve problems, so it is always finding new ways, new results even better than before. (7) Independent, ie attitudes and behaviors that are not dependent on others in completing various tasks and problems. But this does not mean not to collaborate collaboratively, but should not throw duties and responsibilities to others. (8) Democratic, ie attitude and way of thinking that reflects equality of rights and duties fairly and equitably between himself and others. (9) Curiosity, which is the way of thinking, attitude, and behavior that reflects the curiosity and curiosity of all things seen, heard and studied in more depth. (10)The spirit of nationalism or nationalism, ie attitudes, and actions that put the interests of the nation and state above personal or individual interests and groups. (11)Love the homeland, the attitude and behavior that reflects pride, loyalty, care, and high appreciation of the language, culture, political, political, and so on, so it is not easy to accept the offer of another nation that can harm the nation itself. (12) Respect for achievement, ie open attitude toward the achievement of others and acknowledge the lack of self without reducing the spirit of achievement is higher. (13) Communicative, happy to be friendly or proactive, ie attitude and open action to others through polite communication so as to create collaborative collaboration well. (14) Peaceful love, ie attitude, and behavior that reflects the atmosphere of peace, safe, calm, and comfortable for his presence in a particular community or community. (15)Fond of reading, ie the habit of being free to spend time in particular to read various information, whether books, 
journals, magazines, newspapers, and so on, giving rise to policies for him. (16)Caring for the environment, ie attitude and actions that always try to maintain and preserve the surrounding environment. (17)Social care, ie attitudes, and actions that reflect concern for others and communities who need it. (18) Responsibility, namely the attitude and behavior of a person in carrying out duties and obligations, whether relating to self, social, community, nation, state, and religion.

\section{Integrated Thematic Learning}

Along with the implementation of the policy of regional autonomy in the state system, in the education sector, this policy provides widespread space for educational institutions, especially primary schools in managing existing resources, by allocating all the potentials and priorities so as to make breakthroughs of the learning system more Innovative and creative.

One of the creative efforts in implementing learning that uses the competency-based curriculum in primary school is to do thematic learning. Learning this model will be more interesting and meaningful for the children because this learning model presents more actual and contextual learning themes in everyday life.

Currently, character education learning should not use the form of advice or theory students must follow or obey about their morals. Suggestions and theories are not easily accepted in the mind because they need to learn with fun, active, and creative. That way, the value of the character that must be implanted in the mind is acceptable.

In the grand design of the National Policy on Character Education 2010 on the micro context that the integrated character education through the development of the culture of the school, extracurricular activities, community participation, and teaching and learning.

In elementary schools in Indonesia learning has practiced integrated thematic principles, TR Joni (in Triyanto, 2007: 6) states that integrated thematic learning is a learning system that allows students, individuals or groups, actively seek, explore, and discover scientific concepts and principles Holistic, meaningful, and authentic. Integrated learning is based on authentic events or topic exploration as part of learning activities. Students are actively involved in exploration or event topics. Hadisubroto (2005: 5) states that integrated thematic learning is learning that starts from a certain topic or theme that is intentionally (or spontaneously) connected to other topics, certain concepts to other concepts, in one or more subjects, and with various learning. The learning experience will be more meaningful.

Integrated thematic learning is a kind of learning that is very concerned with the development of students by giving the concept based on the level of its development. Integrated thematic learning brings together some subject matter into the same theme.

Thematic learning can be defined as a learning activity by integrating multiple subject matter in one theme/topic of discussion. Sutirjo and Sri Istuti Mamik (2004: 6) stated that thematic learning is an attempt to integrate knowledge, skills, values, or learning attitudes, and creative thinking using themes. From these statements can be emphasized that thematic learning is done with the intent of improving and improving the quality of education, especially to offset the density of curriculum materials. In addition, thematic 
learning will provide integrated learning opportunities that emphasize more on student participation/involvement in learning. Integration in this learning can be seen from aspects of the process or time, aspects of the curriculum, and aspects of teaching and learning.

Integrated thematic learning is learning that is packed in the form of themes based on the content of several subjects that are integrated or integrated (Hence, the values of the characters are integrated in all subjects by linking some material or Concepts on the subject as a whole so as to provide students with meaningful and holistic experiences.

In applying and implementing thematic learning, there are several basic principles that need to be considered: 1) are integrated with the environment, 2) the form of learning is designed so that students find the theme, and 3) efficiency. In order to obtain a clearer picture, the following will be described the three principles, the following.

1. Contextual or integrated with the environment.

The lessons learned need to be packed in a linkage format, meaning that the discussion of a topic is related to the conditions faced by the student or when the student finds the problem and solves the real problem facing the student in daily life is related to the topic discussed.

2. The form of learning should be designed so that students work in earnest to find real learning themes as well as apply them. In conducting thematic learning students are encouraged to be able to find themes that really fit with the condition of students, even experienced students.

3. Efficiency

Thematic learning has efficiency value, among others, in terms of time, material load, method, use of authentic learning resources so as to achieve the right competence mastery.

\section{Character Education at Public Elementary School Rampal Celaket 1 Malang}

Public Elementary School Rampal Celaket 1 Malang has implemented character education based on Curriculum 2013 since 2012 Curriculum implemented in 2012. Implementation of character education in Public Elementary School Rampal Celaket 1 Malang through a comprehensive approach that is to intervene and integrate value education into all school programs (Akbar, 2011: 16). Planting of character values in the learning activities in Public Elementary School Rampal Celaket 1 Malang integrated on thematic learning with a scientific approach.

In addition, the cultivation of character values in class IV Public Elementary School Rampal Celaket 1 Malang is done orally in the form of good attitude directions to students in accordance with the value of characters developed by teachers in Teaching Plan. The value of the internalized character in the learning is adapted from KI-1 and KI-2 and 18 characters according to the Ministry of National Education both in planning and implementation. According Gunawan (2012: 224) states that the integration of character education in the learning process implemented from the planning, implementation, and evaluation of learning in all subjects. In other words, teachers can modify learning planning (designing learning activities and assessment in the syllabus, TEACHING PLAN, and teaching materials), implementing learning process, and evaluation and follow-up in the achievement of targeted learning by integrating the values of characters in it. 
This study focuses on the implementation of character education, the values of the internalized characters, the characters that appear in the students, the obstacles encountered and the solutions implemented by teachers in the implementation of character education on thematic learning in the fourth-grade Public Elementary School Rampal Celaket 1 Malang. In the hope that students can develop their potential, live and internalize the noble values into their personality embodied in everyday behavior, so as to be able to contribute productively to the community and develop the life of a dignified nation.

\section{Method}

This research uses qualitative research approach and descriptive research type with case study research design. Case studies are defined as a direct method of inquiry with a natural setting and focusing on an event intensively and in detail. Ulfatin (2013: 41-42). Events in case studies can be a unique process and phenomenon to be investigated and to develop in-depth knowledge of the object under investigation, so the nature of the research is more explorative and descriptive.

The presence of researchers in the location of research is absolutely necessary because researchers as an instrument as well as collecting data from his research. Therefore, researchers must go directly to the location of research in Public Elementary School Rampal Celaket 1 Malang City addressed at Jalan Tretes Selatan No. 26 Klojen Malang City. This research was conducted for 6 days ie 6 lessons in 1 subteams on theme 7 in class IV in the even semester of academic year 2015/2016. Sources of research data are taken from the subject or informant that is the fourth-grade teacher and documents taken from the source of written data and photographs.

This research procedure uses observation techniques, interviews, and documentation. Data analysis by means of data exposure as a whole, conducting data reduction in accordance with the focus of the problem, and verification and withdrawal of data. Checking the validity of the findings of this research by means of direct observation in the field and triangulation of methods of checking and analysis of data from interviews, observations and documentation related to the implementation of character education on thematic learning in fourth-grade Public Elementary School Rampal Celaket 1 Malang.

\section{Results and Discussion}

Based on data collection in the field, some data analysis from the observation result, interview and documentation are done according to the focus of this research problem. Here is a description of the results and discussion of this study.

\section{Implementation of Character Education in Thematic Learning}

Fourth-grade teacher Public Elementay School Rampal Celaket 1 Malang city integrates character education through planning, implementation, evaluation, and follow-up in learning. Integrating the values of the characters in the learning of the teacher in accordance with the opinion Gunawan (2012: 224) which states that the integration of character education in the learning process implemented from the planning, implementation, and evaluation of learning in all subjects.

Teachers' lesson planning by modifying syllabus and Teaching Plan by integrating character values through objectives, materials, approaches, methods, models, activities, 
learning resources and media, and attitude assessment. This is in line with the opinion of Gunawan (2012: 225) that in the syllabus and Teaching Plan in order to facilitate the occurrence of learning that helps students in developing the character can be done through the addition and or modification of learning activities, achievement indicators and assessment techniques that develop character values.

In the implementation activities, there are preliminary activities, core, and cover. Here is the implementation of character education on integrated thematic learning in the fourth grade Public Elementary School Rampal Celaket 1 Malang.

Table 1 Implementation of Character Education in Thematic Learning in Class IV

\begin{tabular}{|c|c|c|}
\hline No & $\begin{array}{l}\text { Implementation of Thematic Learning that } \\
\text { Integrated Character Values }\end{array}$ & Character Values \\
\hline \multirow{3}{*}{1} & Premilinary Activities & Religious, social care \\
\hline & $\begin{array}{l}\text { Students pray and are invited to pray for a sick } \\
\text { friend } \\
\text { Teachers and students greet each other } \\
\text { Teachers and students sing National songs } \\
\text { The teacher checks for student attendance } \\
\text { The teacher aperception with question and } \\
\text { answer } \\
\text { Teachers convey the purpose and theme of } \\
\text { learning }\end{array}$ & $\begin{array}{l}\text { Religious, } \\
\text { Love the homeland } \\
\text { Discipline } \\
\text { Student curiosity }\end{array}$ \\
\hline & \multicolumn{2}{|l|}{ Core Activities } \\
\hline \multirow[t]{2}{*}{2} & $\begin{array}{l}\text { Scientific approach } \\
\text { Observe } \\
\text { Students observe images, videos, concrete objects and } \\
\text { the surrounding natural environment } \\
\text { Ask } \\
\text { Students are asked to ask what they do not know yet } \\
\text { Try } \\
\text { Students collect information from reading activities; } \\
\text { Ask and experiment / experiment / practice } \\
\text { Reasoning } \\
\text { Students discuss group to do a task; Students answer } \\
\text { questions / make conclusions. } \\
\text { Communicating } \\
\text { Students deliver the results of oral and written } \\
\text { discussions; Students listen and respond }\end{array}$ & $\begin{array}{l}\text { Meticulous, thorough } \\
\text { Curiosity, critical, } \\
\text { confident, tolerant } \\
\text { Thorough, meticulous, } \\
\text { confident, avid reader, } \\
\text { independent } \\
\text { Communicative, } \\
\text { respectful of opinion, } \\
\text { responsibility, tolerance, } \\
\text { democracy } \\
\text { Confident, courageous, } \\
\text { opinion-driven, } \\
\text { responsible, meticulous }\end{array}$ \\
\hline & $\begin{array}{l}\quad \text { Scientific approach } \\
\text { Observe } \\
\text { Students observe images, videos, concrete objects and } \\
\text { the surrounding natural environment } \\
\text { Ask } \\
\text { Students are asked to ask what they do not know yet } \\
\text { Try } \\
\text { Students collect information from reading activities; } \\
\text { Ask and experiment / experiment / practice } \\
\text { Reasoning }\end{array}$ & $\begin{array}{l}\text { Meticulous, thorough } \\
\text { Curiosity, critical, } \\
\text { confident, tolerant } \\
\text { Thorough, meticulous, } \\
\text { confident, avid reader, } \\
\text { independent } \\
\text { Communicative, } \\
\text { respectful of opinion, } \\
\text { responsibility, tolerance, } \\
\text { democracy }\end{array}$ \\
\hline
\end{tabular}




\begin{tabular}{|c|c|c|}
\hline & $\begin{array}{l}\text { Students discuss group to do a task; Students answer } \\
\text { questions / make conclusions. } \\
\text { Communicating } \\
\text { Students deliver the results of oral and written } \\
\text { discussions; Students listen and respond } \\
\text { Learning methods } \\
\text { The teacher uses lecture methods, frequently asked } \\
\text { questions, discussions, assignments, and } \\
\text { demonstrations } \\
\text { Learning model } \\
\text { Teachers applying the model of cooperative learning } \\
\text { with contextual learning, meaningfulness and } \\
\text { interactive; Teacher as a facilitator } \\
\text { Class management } \\
\text { The division of seats in a heterogeneous group; rolling } \\
\text { seat } \\
\text { Sources and learning media } \\
\text { Engagement and student interaction in the use of } \\
\text { learning resources and media; Use of thematic student } \\
\text { and teacher books, LKS, pictures, videos, natural } \\
\text { environment, concrete objects. } \\
\text { Motivation, reward, punishment } \\
\text { Advice, reprimand, action and motivation not to } \\
\text { violate the rules; Individual and group approaches; } \\
\text { Giving applause, gifts, and praise; Positive habits such } \\
\text { as using polite and polite language, praying dhuhur } \\
\text { congregation and memorizing multiplication }\end{array}$ & $\begin{array}{l}\text { Confident, courageous, } \\
\text { opinion-driven, } \\
\text { responsible, meticulous } \\
\text { Thorough, independent, } \\
\text { responsible, disciplined, } \\
\text { communicative } \\
\text { Discipline, curiosity, } \\
\text { environmental care, } \\
\text { responsibility, meticulous, } \\
\text { meticulous, independent } \\
\text { Communicative, tolerant, } \\
\text { socially concerned }\end{array}$ \\
\hline & Closing Acitivities & $\begin{array}{l}\text { Confident, } \\
\text { opinion }\end{array}$ \\
\hline 3 & $\begin{array}{l}\text { Students with teachers conclude the material that } \\
\text { has been learned } \\
\text { Providing evaluation questions } \\
\text { Reflect the learning that has been done } \\
\text { Sing National Song } \\
\text { Ber prayer and closing greetings } \\
\text { Picket cleaning class }\end{array}$ & $\begin{array}{l}\text { Responsibility, honest } \\
\text { Confidence, tolerance } \\
\text { Love the homeland } \\
\text { Religious } \\
\text { Discipline, care for the } \\
\text { environment }\end{array}$ \\
\hline
\end{tabular}

In Table 1.1 it can be seen that in the implementation of learning, teachers internalize the values of the characters in each learning activity begins on the planting of religious values, love of the homeland and discipline on the preliminary activities and the cover of learning.

Preliminary activities that have been done by the teacher are in accordance with the opinion of Gunawan (2012: 230) on Standard Processes in preliminary activities such as preparing students psychologically and physically to follow the learning process, provide students' learning motivation contextually in everyday life, Questions relating prior knowledge to the material to be studied, explaining the learning objectives or basic competencies to be achieved, and conveying the material coverage and explanation of the 
activity description according to the syllabus. It's just that in the preliminary activities, teachers have not provided motivation to students to learn. While in the closing activities conducted by teachers in the table is in accordance with the opinion Gunawan (2012: 233234) which explains that the closing activities of teachers to guide students to make conclusions lessons have been done, perform an authentic assessment, reflect and provide feedback and messages Moral to students. Conclusions in learning are not only related to aspects of knowledge and skills but also attitudes in following the learning.

At the core activities of teachers instill character values through a scientific approach to develop 5M on students: to observe, ask, try, reason, and communicate the content of learning to instill the values of certain characters so that fishing activity of student learning. This is in line with the opinions from Rusman (2015: 231) that the approach is scientific in teacher learning should create active learning through activities to observe, ask, gather information/try, associate/reasoning / processing information, and present / communicate related to the material presented in the Learning Activities.

The teacher uses teaching methods of lectures, questions and answers, discussions, assignments, and demonstrations. In addition, the learning model used is cooperative learning with the teacher as a facilitator of learning. Teacher in classroom management to divide the seating heterogeneous group and perform rolling seat in order to embed the communicative value, tolerance, and social care. This is in accordance with the opinion of Akbar et al (2015: 60) states that the cooperative learning (Cooperative Learning) is a spatial class is composed of groups of students whose members are very heterogeneous both in terms of ability, gender, economic class, religious and other Which can build the value and character of responsibility both individually and collectively, cooperation and rewards to students. In cooperative learning, students can learn from each other and help to learn difficulties among group members with teachers as facilitators who are able to bridge the shortcomings that occur during the discussion process and the task.

The sources and instructional media used by the teachers have varied with the involvement and interaction of students in the use of resources and instructional media. Awarding punishment in the form of advice, warning, action, and motivation of the teachers so that no student is in violation of the rules and their approach to the students individually or in groups, as well as the reward for the provision of applause, gifts, and praise. Things to do fourth grade teacher in accordance with the opinion of Gunawan (2012: 234-235), which explains that there are some things that need to be done to encourage teachers practiced the values of the characters on the implementation of learning that one of them is giving rewards to students who demonstrate character desired and giving punishment to students who deviate from the desired character and reward and punishment can be verbal and non-verbal, greeting card or note of caution and so on.

Assessment (evaluation) on attitude aspect of fourth-grade teacher using observation technique according to instrument and rubric of assessment which contained in Teaching Plan and teacher book and character value observed only some character value only and varied each learning. Assessment conducted by teacher of class IV according to Gunawan's opinion (2012: 235) that assessment technique used to assess attitude aspect or character education especially observation (with observation sheet / observation sheet), self-assessment (with self-assessment sheet / questionnaire) Between friends (assessment sheets between friends), and journal or teacher notes. But teachers only use observation 
techniques, while there are other techniques that can be used in the assessment of attitudes in students such as through self-assessment, assessment between friends, and journals. This is because the teacher's understanding of the various attitudinal assessments is still lacking, so only using attitude assessment through observation only.

The follow-up that the teacher gives to the students aims to integrate and instill the values of independent, honest, disciplined and responsible characters to the tasks assigned to the students. This is in line with Gunawan's (2012: 236) opinion on strengthening tasks (especially enrichment ) Are provided to facilitate students learning more about the competencies being studied and internalizing the value further.

\section{The Value of Characters Internalized in Thematic Learning}

Character values internalized teacher in the thematic visible from the planning and implementation of learning that integrates the values of the characters of on first quadrant (Q-1) and Second Quadrand (Q-2) on the Curriculum 2013 and 18 characters according to the Ministry of National include religious character, honesty, discipline, tolerance, Social concern, self-reliant democratic, curiosity, communicative, caring environment, love the homeland, appreciate achievement, love to read, and responsibility. These values are not communicated directly to the students, but implicitly in the way teachers act and teach by the teacher.

The values developed are in accordance with the values of cultural education and national character identified by the Ministry of National Education in 2010 (in Wibowo, 2013: 1415) that is religious, honest, tolerant, disciplined, hard work, creative, independent, democratic, Know, the spirit of nationality, love the homeland, appreciate achievement, friendly and communicative, love peace, love to read, care environment, social care, and responsibility. In addition, in accordance with Permendikbud Number 57 of 2014 on elementary curriculum that contains the core competence of the spiritual and social attitudes of fourth-grade students. Competence The essence of spiritual attitudes (KI-1) on religious values is receiving, practicing and appreciating the religious teachings that it embraces. Social attitudes and core competencies (KI-2) students have honest behavior, discipline, responsibility, manners, caring, and confident in interacting with family, friends, teachers, and neighbors.

\section{Character that appears on the Thematic Students in the Learning Process}

Values characters appear in the learning process of thematic class IV Public Elementary School Rampal Celaket 1 Malang related to attitude, behavior and action of students who demonstrated on the activities of the introduction, the core and the cover there is a 12character value among another religious character, honesty, tolerance, discipline, self, love of country, respect for achievement, curiosity, communicative, caring environment, social care, and responsibility for society.Dengan thus, 12 values of the characters that appear in the process of thematic learning in class IV are in accordance with the value of the nation's culture and character education identified by the Ministry of National Education in 2010 (in Wibowo, 2013: 14-15), namely religious, honesty, tolerance, discipline, hard work, creative, independent, democratic, curiosity, the spirit of nationalism, love of country, respect for the achievements, friends and communicative, love peace, love reading, environmental care, social care, and responsibility. Of 18 characters according to MONE there are 12 characters who have been looked at me in the fourth-grade students of the thematic learning process. 
Teachers obstacles in the implementation of Character Education in Teaching Thematic

Master class IV in implementing character education thematic learning experience obstacles / difficulties: (1) planning to develop the indicators of learning that integrates the values of characters in Teaching Plan, (2) the implementation of learning in terms of time constraints to instill the values of character especially value honesty in students due to lack of support from parents in giving homework, and (3) assessment of learning that require a long time and the process of inference character on students because so many students and the characters are observed. Therefore, teachers need considerable time to embed, observe and assess the attitude of all students in a given time period in both the process and the results indicated conclusions student character value.

In accordance with the opinion Wibowo (2012: 96), which explains that assessment is done continuously, every time the teacher is in the classroom or school. Teachers can use anecdotal records (records are made of teachers when looking at their behavior with respect to the value which was developed) and gives the task of providing opportunities for students to demonstrate its value.

Thus, the barriers experienced by teachers in implementing character education thematic learning because teachers lack factor implement monitoring the activities of planning, implementation, and evaluation. Therefore, teachers need to pay attention in school learning conducted in accordance with the opinion Sahlan and Prastyo (2012: 92-93) states that the planning process for the assessment of learning, teachers need to conduct monitoring to show a clearer understanding of the learning plan as the target destination learning. In order to examine and reduce the limiting factors in learning.

\section{Master Solutions Overcoming Barriers to the Implementation of Character Education in Teaching Thematic}

Teachers implemented solutions to overcome obstacles in implementing character education are the first thematic learning in the planning adjust teacher learning achievement indicators of knowledge and skills with the learning method that allows internalizing the character values in the learning activities. This is in accordance with the opinion of Akbar (in the interview) that planning the implementation of learning (Teaching Plan) it starts from learning material analyzed from KI-3 is about knowledge, then decreased to KI-4 (skills) relevant to the KI-3. Then determine the methods and the learning model will lead to the planting of character values contained in the KI-1 and KI-2 in learning.

Second, teachers in the implementation of thematic learning do both personal and group approach to students with an overview and motivation for the provision of the expected value character. In addition, teachers in instilling the values of character, especially honesty ask for help opinion and consulted with colleagues / other teachers, principals and parents to discuss student behavior at school with the expectations of parents can actively participate in supporting their children's education, including embedded character education in schools. Things to do in accordance with the opinion of teachers Kesuma et al (2013: 9-10), which states that the purpose of the third character education is character education as a school setting that is establishing connections with family and community harmony in the play's responsibility collectively character education. 
Third, learning assessment techniques implemented gradually through the observation and assessment rubrics contained in attitude TEACHING PLAN made. The assessment was conducted during and after the learning takes place by observing the behaviors and attitudes that stand out on students or at the time showed character to be expected at the group and individual activities. This is in line with the opinions Wibowo (2012: 96) states that the assessment is done continuously, every time the teacher is in the classroom or school. However, in the assessment of teachers have varying attitudes attitude assessment techniques such as self-assessment, peer assessment, and teacher journals or notes.

\section{Conclusion}

Implementation of character education in thematic learning has been implemented with good teachers through the integration of character values through planning, implementation, evaluation and follow-up study. In addition, teachers have been integrating the values of the characters on the use of models, methods, approaches, resources and instructional media. With the value of the developed character that is religious, honesty, discipline, tolerance, social care, independent, democratic, curious, communicative, love of country, respect for the achievements, care for the environment, love reading, and responsibility.

The values of the characters that have been internalized teacher in the thematic namely religious, honesty, discipline, tolerance, social care, independent, democratic, curious, communicative, caring environment, love of country, respect for the achievements, like reading, and responsibility. In thematic learning process takes place fourth graders already reveals a religious character, honesty, tolerance, discipline, self, love of country, respect for achievement, curiosity, communicative, caring environment, social care, and responsibility.

Obstacles encountered in the fourth-grade teachers implement character education thematic learning due to lack of monitoring of learning. Barriers or obstacles that teachers lesson plans that integrate the values of the characters on the indicator, time constraints in instilling the values of characters in the learning process and the lack of support from parents, as well as evaluating attitudes and processes that require a long time.

Solutions are implemented teacher to overcome obstacles in implementing character education thematic learning that teachers had to adjust the indicators of learning with the learning method to internalize the character values in the learning activity, approached both personal and group to the students and discuss the behavior of students in schools with teachers, principals, and parents. In addition, teacher assessment gradual attitude with the technique, instruments, and observation guide section on Teaching Plan.

Research findings showed that the implementation of character education in thematic learning through planning, implementation, evaluation, and follow-up to develop the value of religious character, honesty, discipline, tolerance, social care, independent, democratic, curious, communicative, caring environment, love homeland, recognize excellence, love reading, and responsibility in students. Therefore, teachers are advised to integrate the values of characters in the planning implementation, evaluation or assessment and followup in thematic learning. 
Based on the values of the characters that have been internalized teachers in the planning and implementation of learning that is religious, honesty, discipline, tolerance, social care, independent, democratic, curious, communicative, caring environment, love of country, respect for the achievements, fond of reading, and responsible. Therefore, it is suggested that teachers can internalize these values in each thematic learning is done.

The process of implementation of thematic learning in class IV shows the characters that appear on students that religious character, honesty, tolerance, discipline, self, love of country, respect for achievement, curiosity, communicative, caring environment, social care, and responsibility. Therefore, it is suggested that teachers can reveal character values that are embedded on students in any learning process is implemented.

Fourth-grade teacher obstacles in the implementation of character education in thematic learning that is in the planning, implementation, and evaluation. It is recommended to teachers in a plan to develop indicators of learning that integrates the values of character, add instructional time and ask the support of the school and their parents in instilling values, and adds time to the assessment of the attitude of the students.

Teachers to overcome obstacles in the implementation of character education can thematic learning through planning, implementation, and assessment. Therefore, it is suggested that teachers can make planning more emphasis on integrating the values of character, conduct and strengthen the cooperation between the school and parents of students in the planting of a good attitude and varying techniques, the assessment carried out as a self-assessment, assessment between friends, and journal/teacher records.

Based on the findings, this study has its limitations are less steeped in coverage at the time, the assessment took place related to the value of attitude. To that end, the researchers suggested that further develop similar research on aspects of assessment that teachers do attitude of both the process and the results of the assessment to internalize the character values.

\section{References}

Akbar, Sa'dun. 2011. Revitalization of Character Education in Primary Schools. Paper presented at the Inauguration of the field IlmuPendidikan / Elementary Education. June 8th, Malang: UM (Online)

(http://digilib.um.ac.id/images/story/pidatogurubesar/2011/REVITALISASI\%20PENDIDI KAN\%20KARAKTER\%20DI\%20SEKOLAH\%20DASAR520Prof\%20Sa\%20DUN\%20 aKBAR.pdf), accessed December 23, 2015.

Akbar, Sa'dun, Celestial, Ahmad, Arafik, Muh. \& Hidayah, Layli. 2015. Character Education: Best Practices. Malang: The Negeri Malang University.

Casey, Cort and Kinkopf, Timothy. 2016. Character Education: Teachers' Perceptions of its Implementation in the Classroom . Delta University: Delta Journal of University Gunawan, Heri. 2012. Character Education Concept and Implementation . Bandung: Alfabeta.

Hadisubroto. 2005. Integrated Learning: Topic PGSD . Jakarta: The Open University. Kesuma, Dharma, Triatna, CEPI, and Permana, Johar.2013. Character education (Study of Theory and Practice in Schools). Bandung: PT Remaja Rosdakarya.

Khan, Y. 2010. Character Education Boosting Potential Based on Education. Jogjakarta: Pelangi Publishing. 
The Government of the Republic of Indonesia. 2010. The National Policy for the Year 2010-2025 National Character Development. Jakarta: Ministry of National Education. (On line). (

Http://fisip.ilearn.unand.ac.id/pluginfile.php/879/mod_resource/content/1/Desain-IndukPendidikan-Karakter-Kemdiknas.pdf ), accessed January 18, 2016.

Rusman. 2015. Learning Integrated Thematic (Theory, Practice, and Assessment) . Jakarta: King Grafindo Persada.

Sahlan, Asmaun \& Teguh Angga Prastyo. 2012. Design-Based Learning Character Education . Jogjakarta: Ar-Ruzz Media.

A copy of the Appendix Permendikbud No. 57 Year 2014 on Basic Framework and Curriculum Structure of Primary School / Elementary School.

Sutirjo and Sri Istuti Mamik. (2005). Thematic: Effective Learning in the 2004 curriculum. Malang: Bayumedia Publishing.

Ulfatin, Nurul. 2013. Qualitative Research Methods in Education: Theory and Applications). Malang: Faculty of Education, State University of Malang.

Trianto. (2007). Integrated Learning Model: Theory and Practice. Jakarta: Performance Library.

Wibowo, Agus. 2012. Character Education: Character-Building Strategy Civilized Nations. Yogyakarta: Student Literature.

Wibowo, Agus. 2013. Management of Character Education in Schools (Concepts and Practices Implementation). Yogyakarta: Library Learning. 